\title{
ADULARIA ASSOCIATED WITH EPITHERMAL GOLD VEINS IN THE TAPAJÓS MINERAL PROVINCE, PARÁ STATE, NORTHERN BRAZIL.
}

\author{
ANA M. DREHER*, SILVIO R. F. VLACH** \& SÉRGIO L. MARTINI*
} \begin{abstract}
RESUMO ADULARIA ASSOCIADA A VEIOS EPITERMAIS DA PROVÍNCIA AURÍFERA DO TAPAJOS, PARÁ, BRASIL. O feldspato
potássico da variedade adularia foi encontrado nos prospectos de ouro primário do Davi e do Joel, situados na área da Província Mineral do Tapajós, sudoeste do Pará. Em ambas as ocorrências, a adularia preenche fraturas e cavidades intimamente associadas aos veios de quartzo mineralizados, tendo como encaixantes rochas subvulcânicas máficas proterozóicas hidrotermalmente alteradas. A adularia constitui cristais pequenos (1 -4 mm), vermelhos ou róseos, de morfologia pseudo-ortorrômbica, tendo-se identificado o hábito Felsöbanya em cristais da localidade do Joel. Análises de microssonda mostram que a adularia tem composição muito pura e próxima ao termo extremo $\mathrm{KalSi}_{3} \mathrm{O}_{8}$. Dados de difração de raios-X indicam que o feldspato corresponde a tipo dominantemente triclínico com estado estrutural próximo ao do microclínio máximo. Este alto grau de ordenamento é relativamente raro em adularia e pode ser atribuído à ação extensiva de fluidos tardios sobre cristais originalmente metaestáveis e desordenados, cuja forma monoclínica primitiva permanece ainda preservada. $\mathrm{O}$ estudo de inclusões fluidas em cristais de quartzo adjacentes a adularia mostra que os feldpatos formaram-se sob temperaturas de $240^{\circ}-320^{\circ} \mathrm{C}$ no Davi e de $220^{\circ}-340^{\circ} \mathrm{C}$ no Joel. Os fluidos aprisionados são isentos ou muito pobres em $\mathrm{CO}_{2}$ de modo geral pouco salinos. Os valores médios de salinidade são de 1,15 para o Davi e 0,43 para o Joel, excepcionalmente atingindo teores de até 11 eq. \% em peso $\mathrm{NaCl}$. Utilizando a presença da própria adularia como indicativa de ebulição, é possível estimar uma profundidade de até 1,5 km para a formação da adularia e dos veios de quartzo associados. A presença de adularia nos prospectos do Davi e Joel traz um importante reforço para a definição da tipologia do ouro do Tapajós, já que este feldspato constitui-se num mineral típico dos depósitos epitermais da categoria adulária-sericita. A natureza epitermal dessas ocorrências pode também ser atestada por outras feições, como por exemplo o caráter não-metamórfico das encaixantes dos veios e seu padrão de alteração hidrotermal; as texturas de preenchimento de espaços abertos dos veios e a assembléia de minerais presentes; e a natureza rúptil da deformação impressa nos veios e encaixantes. A composição dos fluidos em inclusões situa-se igualmente dentro dos limites admitidos para depósitos epitermais a adulária-sericita. As temperaturas de formação dos veios de quartzo e adularia, por sua vez, pertencem a uma faixa de temperaturas elevadas em depósitos epitermais, sugerindo que os prospectos do Davi e Joel correspondam a exposições de partes profundas e de mais alta temperatura dos respectivos sistemas hidrotermais. Dois outros aspectos merecem ênfase em relação à definição de uma tipologia epitermal para a região do Tapajós. A idade proterozóica é excepcionalmente antiga para este tipo de depósito, já que a maioria dos representantes no mundo são cenozóicos. Além disso, a definição é interessante para prospecção pois o tipo tem potencial para gerar bulk deposits de grande tonelagem.
\end{abstract}

Palavras-chave: adularia, Província Mineral do Tapajós, ouro, tipologia, epitermal, depósitos a adulária-sericita.

ABSTRACT The potassium feldspar variety adularia was found in the Davi and Joel primary gold prospects located in the Tapajos Mineral Province, southwestern Pará State, Brazil. In both areas adularia occupies fractures and vugs intimately associated with mineralized quartz veins hosted by hydrothermally altered Proterozoic subvolcanic mafic rocks. Adularia constitutes small (1-4 mm) red to pink crystals of pseudo-orthorhombic form. The Felsöbanya habit was identified in specimens from the Joel prospect. Microprobe analyses show that adularia has a composition near to pure $\mathrm{KalSi}_{3} \mathrm{O}_{8}$. X-ray diffraction data indicate that the feldspars correspond to predominantly triclinic types with structural state near that of maximum microcline. This high degree of ordering is relatively rare in adularia and may be attributed to the extensive action of late fluids over originally metastable, disordered crystals whose primitive monoclinic form is still preserved. Fluid inclusion studies in quartz crystals adjacent to adularia show that the feldspar formed under temperatures of $240^{\circ}-320^{\circ} \mathrm{C}$ at Davi and $220^{\circ}-340^{\circ} \mathrm{C}$ at Joel. The trapped fluids are poor in or devoid of $\mathrm{CO}_{2}$. Fluid salinity was low, averaging 1.15 at Davi and 0.43 at Joel, attaining exceptionally values up to 11 wt.\% $\mathrm{NaCl}$ equivalent. Considering that the presence of adularia is indicative of boiling, it is possible to estimate a maximum depth of $1.5 \mathrm{~km}$ for the formation of adularia and the associated quartz veins. The presence of adularia in the Davi and Joel prospects is important in the definition of the typology of primary gold of the Tapajós Province as this feldspar is a typical mineral of epithermal deposits of the adularia-sericite category. Other features also point to the epithermal nature of the mentioned occurrences. These include the non-metamorphic character of the host rocks and their hydrothermal alteration pattern; the open-space filling textures of the veins and their mineral assemblage; and the brittle nature of the deformation imprinted in both veins and wallrocks. The composition of fluids in inclusions also lies within the limits admitted for adularia-sericite epithermal deposits. The temperatures of formation of the adularia and quartz veins, in turn, belong to a high temperature rank in epithermal deposits, suggesting that the Davi and Joel prospects correpond to exposures of the deeper, higher temperature sectors of their original hydrothermal systems. Two other aspects should be emphasized concerning the definition of an epithermal typology for gold occurrences in the Tapajós region. The Proterozoic age is an unusually old one for this type of deposit, as the majority of their representatives in the world are Cenozoic; and the definition is interesting for gold exploration in connection with the potential for bulk-tonnage deposits.

Keywords: adularia, Tapajós Mineral Province, gold, typology, epithermal, adularia-sericite deposits.

INTRODUCTION Adularia is a variety of potassium feldspar characterized by a pseudo-orthorhombic crystal form that occurs typically in low-temperature, hydrothermal environments (Smith 1974a). Adularia is also known for the wide range of its optical and structural properties, occasionally even in a single crystal. Its structural state may vary from close to ordered maximum microcline to extremely disordered high sanidine. Such diversity is dependent on the conditions of crystallization and the thermal history following the crystallization of the mineral (Czerný and Chapman 1984,1986)

One of the most common and at the same time most important references to adularia is found in connection with epithermal preciousand base-metal deposits, where the mineral occurs as a typical and distinctive gangue phase of the so-called adularia-sericite deposit type of Heald et al. (1987). In the other category of epithermal deposit known as the acid-sulfate type, adularia is systematically absent

During recent geological fieldwork in the Tapajós Gold Province, in southwestern Pará State, adularia was found in two primary gold occurrences, namely the Davi and the Joel mining prospects. At both sites, adularia occurs in fractures and late-stage cavities hosted by hydrothermally altered mafic rocks and intimately associated to mineralized quartz veins. Other features exhibited by the gold-bearing veins and their wallrocks strongly suggest that these occurrences are epithermal in origin.

* CPRM-Serviço Geológico do Brasil, Av. Pasteur 404, CEP 22290-240 Rio de Janeiro, RJ, Brazil, e-mail: amdreher@cristal.cprm.gov.br/ sergio@cristal.cprm.gov.br

** Departamento de Mineralogia e Petrologia, Instituto de Geociências, Universidade de São Paulo, Caixa Postal 11348, CEP 05422-970 São Paulo, SP, Brazil. e-mail: srfvlach@usp.br
In addition to describing the Davi and Joel occurrences, this paper presents the results of detailed studies, carried out on selected samples of adularia that led to its identification and characterization in the two above-mentioned prospects. These studies are based on morphological, microprobe, X-ray and fluid inclusion data. The genesis of adularia is discussed, and its significance in the definition of the typology of gold deposits of the Tapajós Gold Province is emphasized.

Analytical Procedures Several adularia-bearing rock and vein samples collected in the Davi and Joel prospects were examined with the aid of a stereo microscope and also in thin sections under a petrographic microscope. The three most representative adularia vein samples were chosen for detailed microprobe, X-ray and fluid inclusion studies.

Microprobe analyses were carried out on polished thin sections at the Institute of Geosciences of the University of São Paulo. A combined Jeol-JXA8600S / Noran-TN-5600 system was used, operating under $15 \mathrm{kV}$ and $20 \mathrm{nA}$, with a defocused $10 \mathrm{~nm}$ electronic beam. Maximum counting integration times were $20 \mathrm{~s}$ for the major elements, $30 \mathrm{~s}$ for $\mathrm{Na}$ and $60 \mathrm{~s}$ for the remaining elements. Natural Asbestos microcline $(\mathrm{Si} \mathrm{K} \alpha, \mathrm{Al} \mathrm{K} \alpha, \mathrm{K} \mathrm{K} \alpha)$, Amelia albite $(\mathrm{Na} \mathrm{K} \alpha)$, barite $(\mathrm{Ba} L \alpha)$, paracelsian $(\mathrm{Cs} L \alpha)$, and synthetic hematite $(\mathrm{Fe} \mathrm{K} \alpha)$ 
and anorthite $(\mathrm{Ca} \mathrm{K} \alpha, \mathrm{Sr} \mathrm{L} \alpha)$ were used as standards. A Proza matrix correction and data reduction program (e.g. Bastin et al. 1984) provided by Noran was applied.

X-ray powder data were collected on a Phillips PW-1710 automated diffraction system at the Polytechnic School of the University of São Paulo. Samples were scanned from $10^{\circ}$ to $80^{\circ}(2 \theta)$ in $0.005^{\circ}$ steps with counting times of $1 \mathrm{~s} / \mathrm{step}$ using monochromated $\mathrm{CuK \alpha}$ radiation. Metallic Si $\left(\mathrm{a}_{0}=5.43083 \AA\right)$ admixtured during sample pulverization was used as an internal standard in order to correct for equipment drift. The corrected data patterns were indexed following data of Borg and Smith (1969). Unit cell parameters were refined using the least squares procedure of Burnham (1962) considering about 30 peaks for each sample.

Fluid inclusion data were obtained on double polished thin sections using Linkam TMSG-600 and Chaixmeca MTM-85 heating-freezing stages at the Institute of Geosciences of the University of Campinas. A total of 68 measurements were made on quartz crystals adjacent to adularia. Synthetic inclusions manufactured by Synflinc were chosen for standards. No error was detected for ice melting experiments but homogenization temperature measurements showed deviations of $\pm 5^{\circ} \mathrm{C}$ above $100^{\circ} \mathrm{C}$. Fluid salinities were obtained from freezing point depression data using the tables of Bodnar (1993).

\section{BRIEF GEOLOGY OF THE TAPAJÓS GOLD PROVINCE}

The Tapajós Gold Province is located in the southwestern part of Pará State, northern Brazil and comprises an area of about $90.000 \mathrm{~km}^{2}$. It occupies the central portion of the southern half of the Amazon Craton, which obtained stability by the end of the Lower Proterozoic (Schobbenhaus et al. 1984).

The region is underlain by Precambrian rocks (Santos and Loguercio 1984, Faraco et al. 1996), which can be conveniently divided into three general age units (Fig. 1). The oldest one consists of Archean (?) to Lower Proterozoic Cuiú-Cuiú gneisses and Parauari granitoids with subordinated greenstones and unmetamorphosed Ingarana mafic intrusive bodies. The other unit comprises Middle Proterozoic, dominantly felsic eruptives and related granites, historically ascribed to the Uatumã Supergroup. The third and youngest unit is made up of a Middle to Upper Proterozoic sedimentary sequence with localized dolerite sills.

THE ADULARIA OCCURRENCES The Davi prospect lies in the Bom Jardim River basin, located in the lower valley of the Crepori River, near the center of the Tapajós Province (Fig. 1). Approximate coordinates are $05^{\circ} 46^{\prime} 50^{\prime \prime} \mathrm{S}$ and $57^{\circ} 01^{\prime} 05^{\prime \prime} \mathrm{W}$. Adularia found at Davi comes from $20 \mathrm{~m}$ deep underground workings following a gold-bearing quartz vein. The vein is hosted by mafic rocks ascribed to the above-mentioned Ingarana unit, of Lower Proterozoic age (Faraco et al. 1996). There are granitoids exposed near the prospect, probably belonging to the Parauari suite, of Lower Proterozoic age as well.

Material found in the surface workings of the Davi prospect include mafic saprolites with preserved slickensides. Fresh rocks exposed underground are petrographically characterized as quartz-diabases and granophyric gabbros (Martini and Dreher 1996a) that belong to a shallow, probably dike-like intrusion. These rocks, though fractured and hydrothermally altered, are unmetamorphosed and in general alteration has not been sufficiently strong to erase igneous textures. Alteration comprises an assemblage of secondary minerals such as chlorite, sericite, carbonate, epidote, leucoxene and pyrite, and may be characterized as propyllitic.

Near the vein there is an alteration envelope, usually less than a few meters thick, where the mafic protolith loses its original texture and displays white calcite-rich patches, as well as veinlets and irregular zones with reddish feldspar, including adularia and hematite-stained albite. Rocks displaying the most intense alteration and strongest cataclastic deformation in the envelope are either quartz-sericitic or black rock types composed of chlorite, prehnite, albite, calcite, epidote and sulfides.

The mineralized quartz vein strikes $\mathrm{N} 45^{\circ} \mathrm{E}$ and dips $70^{\circ} \mathrm{SE}$. It is up to half a meter thick and shows pinch out and disrupted portions in both cross and longitudinal sections. The vein itself is an aggregate of milky, comb-textured quartz affected by repeated cataclasis and brecciation. Pyrite makes up to $10-15 \%$ of the vein, occurring in patches, bands or disseminations. Galena, chalcopyrite, bornite and sphalerite are present in lesser amount. Late calcite and prehnite veins are also present. Adularia consitutes narrow veinlets (Fig. 2A), which usually follow the contact between the quartz vein and the alteration envelope.
The Joel prospect is located about $12 \mathrm{~km}$ east of the Creporizão village (Fig. 1), on the Transgarimpeira road. Local coordinates are $06^{\circ}$ $50^{\prime} 25^{\prime \prime} \mathrm{S}$ and $56^{\circ} 44^{\prime} 05^{\prime \prime} \mathrm{W}$. Adularia specimens collected in this prospect were also obtained from underground workings, more precisely from a narrow dike of diabase which hosts small gold-bearing quartz veins and is worked to a depth of about 10 meters.

The dike is vertical, about 1 meter thick and strikes $\mathrm{N} 50^{\circ} \mathrm{E}$. The wallrock is a pink granite with subhorizontal friction striae along the contacts. As in the case of the Davi prospect, both dike and granite wallrocks are probably of Lower Proterozoic age.

Wherever fresh ou weakly altered, the diabase is clearly non-foliated and distinctly porphyritic, showing white laths of labradoritic plagioclase up to $1 \mathrm{~cm}$ in length, set in a black aphanitic mesostasis. The alteration, also considered of propyllitic nature, affects mostly the rock matrix and comprises chlorite, calcite, sericite, green biotite, epidote and actinolite.

Where more strongly altered, the diabase loses its porphyritic appearance, acquires a greenish tint and develops a brecciated and somewhat foliated structure. Its composition is dominated by sericite and chlorite with lesser epidote and leucoxene. Phenocrysts are fragmented and completely serialized, being observed only under the microscope. Sulfides like pyrite, sphalerite, chalcopyrite and galena occur disseminated in places. More commonly, however, they are concentrated in narrow veins and veinlets of deformed quartz. Gold and silver occur both free and in association with the sulfides, according to Bastos Leal and Tassinari (1994). Adularia in turn occurs in aggregates of idiomorphic crystals, which along with quartz, occupies late-stage fractures and centimetric drusy cavities observed in mineralized and more strongly altered portions of the diabase (Figs. 2B and 2C).

MORPHOLOGY AND OPTICAL FEATURES The adularia found at the Davi prospect is red to dark red in colour and constitutes veinlets a millimeter or so across that commonly follow the contacts between the mineralized quartz vein and its mafic wallrock (Fig. 2A). Adularia in these veinlets is in places associated with albite and is altered to prehnite, calcite and chlorite. It also displays a turbid appearance caused by strong impregnation by hematite and clay minerals. Adularia crystals are very small, attaining $1 \mathrm{~mm}$ in size at most.

The fine grain size and the strong alteration preclude precise identification of crystal forms in hand specimen. In thin section, however, perfectly rhombic sections, characteristic of adularia, can be recognized in crystals that grow towards the center of cavities (Fig. 2D). Other features observed under the microscope are the irregular extinction pattern, more clearly perceived in larger crystals, and tiny areas within the adularia crystals showing microcline-like cross-hatching.

The adularia of the Joel prospect is salmon pink to light pink in colour. It constitutes well developed crystals, euhedral to subhedral in shape and up to 4 millimeters across, which occupies along with quartz fractures and vugs in the more altered and shattered zones of the host diabase (Fig. 2B). Epidote, violet-blue fluorite, calcite and sulfides are occasionally associated with adularia.

Inside the vugs it is possible to identify rhombohedric or pseudoorthorhombic crystals of the so-called Felsöbanya type (Figs. 2C and 3 ), one of the characteristic habits of adularia and formerly considered as a typical morphology in occurrences associated with ore deposits (Kalb 1924, apud Smith 1974b). Under the microscope the mineral exhibits an apparently triclinic symmetry, is B(-) with a moderate $2 \mathrm{~V}$. Its alteration to chlorite, epidote, carbonate and argillic-ferruginous material is weaker than that of the Davi prospect. Moreover, adularia from Joel displays internal crystal textures similar to but more conspicuous than those present in the Davi adularia, including microclinelike cross-hatched domains and different sectors showing varying extinction angles within the same crystal section (Figs. 2E and F).

CHEMICAL COMPOSITION Representative microprobe point analyses results for the Davi and Joel adularia samples are displayed in Table 1. The composition of all samples is in general quite close to the ideal potassium feldspar end-member, with very low contents of non-essential elements, a feature considered typical of adularia (Deer etal. 1971.Czerný and Chapman 1984). BaO contents (0.10-0.50 wt. $\%)$ are those expected for this mineral species. $\mathrm{Ca}, \mathrm{Sr}$ and $\mathrm{Cs}$ are all very near their detection limits $(300-500 \mathrm{ppm})$ and $\mathrm{Rb}$ was not detected in any of the samples even in careful wavelength scans. The high stoichiometry of the adularia chemistry also precludes any major contribution of other anions or aqueous, $\mathrm{NH}_{4}$ or $\mathrm{B}$ species that could enter alkaline-feldspar structure and cause changes in the unit cell dimensions (Kroll and Ribbe 1983, Czerný and Chapman 1984). The 

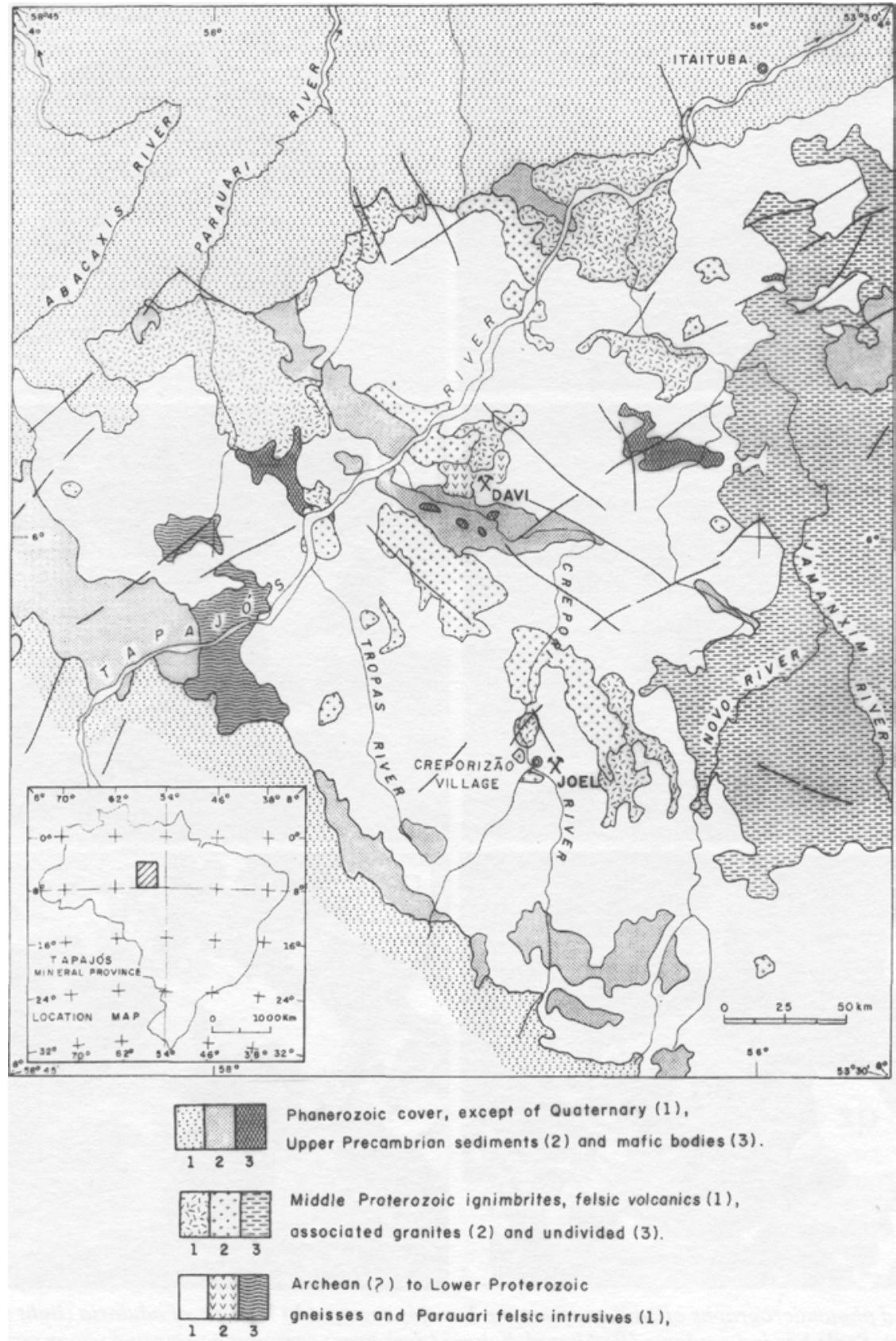

Phanerozoic cover, except of Quaternary (1),

Upper Precambrion sediments (2) and matic bodies ( 3 ).

Middle Proterozoic ignimbrites, felsic volconics (1),

ossociated granites (2) and undivided (3).

Archeon (?) to Lower Proterozoic

gneisses and Parauari felsic intrusives (1),

ingarana mafic bodies (2), greenstones (3).

Figure 1 - Geology of the Tapajós Mineral Province showing location of the Davi and Joel prospect areas. Adapted from Schobbenhaus et al. (1984) and Faraco et al. (1996).

$\mathrm{Al} /(\mathrm{K}+\mathrm{Na}+\mathrm{Ba})$ atomic ratios of all analyses are almost ideal and add to exactly 1 , except in the case of Ad-1.1, which has a slightly metaluminous character.

$\mathrm{Fe}$ and $\mathrm{Na}$ contents are the only contrasting features observed between the Davi and Joel adularia compositions. Samples from Davi (Ad-1, see Table 1) are somewhat Fe-richer and Na-poorer, showing molecular Or $>98$. The Joel feldspars (Ad-2 and Ad-3) show very low or undetected $\mathrm{Fe}$ contents and lower Or proportions, within the range of 93-97. The Fe-rich nature of the Davi adularia correlates with the strong iron staining pointed out previously, a feature that probably resulted from interaction with late iron-rich, oxidizing fluids.

STRUCTURAL STATE Representative partial X-ray diffraction patterns of the sampled adularia from the Tapajós region are presented in figure 4. The well defined (131) and (131) diffraction peaks exhibited by the three samples clearly indicate a predominantly triclinic feldspar symetry. Sample Ad-1 has a typical homogeneous maximum microcline pattern, with a triclinicity $\left(\mathrm{A}=12.5^{*}\left(\left.\mathrm{~d}\right|_{3},-\mathrm{d}\right]_{3}\right.$, $)$ close to 1.0, as defined by Goldsmith and Laves (1954). Samples Ad-2 and Ad-3 have instead broadened and less intense (131) and (1 $\overline{3} 1)$ peaks, with a lower mean triclinicity of about $0.75-0.85$. This indicates the predominance of non-homogeneous, triclinic feldspars but the presence of minor monoclinic domains within them can not be ruled out. A well established method for alkali feldspar structural state analysis takes into account the $\mathrm{Al}-\mathrm{Si}$ atomic distributions within the nonequivalent $\mathrm{T}_{1} \mathrm{O}, \mathrm{T}_{2} \mathrm{O}$, Tjm and $\mathrm{T}_{2} \mathrm{~m}$ tetrahedral sites, which build the four-membered $\mathrm{TO}_{4}$ rings of a triclinic feldspar framework (e.g. Blasi and Blasi 1994). Completely disordered structures have $\mathrm{Al}$ and $\mathrm{Si}$ equally distributed on the $\mathrm{T}$ sites, as for high sanidine. Ordering promotes the preferential migration of $\mathrm{Al}$ and $\mathrm{Si}$ to the $\mathrm{T}_{1}$ and $\mathrm{T}_{2}$ sites, respectively, because the former are more closely bonded to the large $(\mathrm{K}, \mathrm{Na})$ sites. $\mathrm{T}_{1}$ and $\mathrm{T}_{2}$ sites are equivalent in their respective $\mathrm{Al}$ and $\mathrm{Si}$ average content in monoclinic feldspar and orthoclase has all $\mathrm{Al}$ 

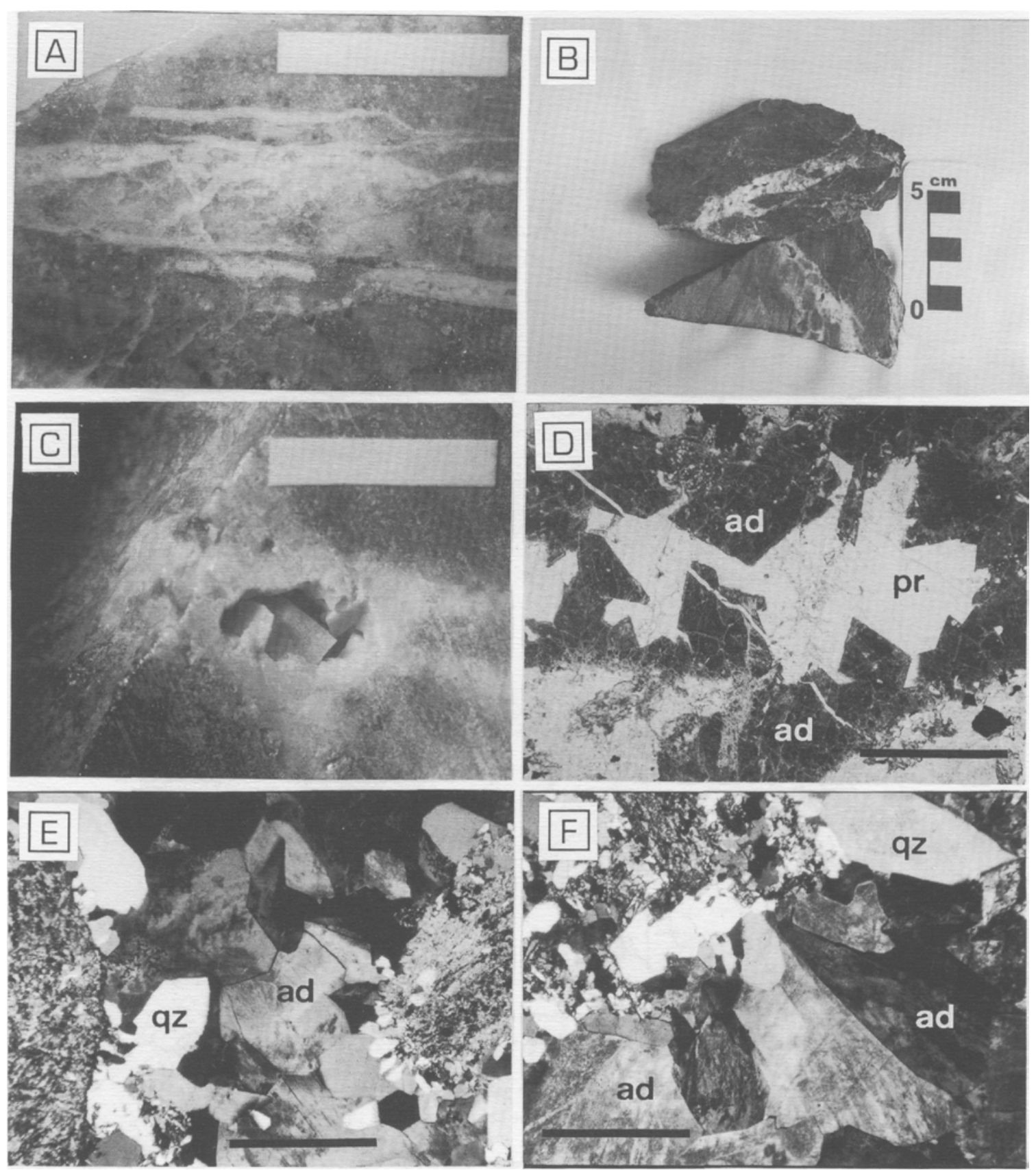

Figure 2 - Photographs and photomicrographs of adularia from the Tapajós region. (A) Veinlets of adularia (light grey) lining a small quartz vein from the Davi prospect. Scale bar is $1 \mathrm{~cm}$ long. (B) Altered diabase (dark grey) containing veins and vuggy cavities infilled with adularia and quartz (light grey). Samples from the Joel prospect. (C) Coarse adularia crystals in a cavity showing the typical pseudo-orthorhombic crystal form known as the Felsöbanya-type morphology. Sample from the Joel prospect. Scale is $1 \mathrm{~cm}$ long. (D) Rhombic crystals of adularia (ad) projecting into a cavity formed in the core of a veinlet. Adularia is dark due to strong hematite staining. The inner part of the cavity is filled with prehnite (pr). Sample from the Davi prospect. Plane-polarized light. Scale is $1 \mathrm{~mm}$ long.(E) Aggregate of idiomorphic quartz (qz) and adularia (ad) crystals grown between fragments of strongly altered diabase. Sample from the Joel prospect. Crossed polarizers. Scale is $1 \mathrm{~mm}$ long. (F) Large adularia (ad) crystals showing complex extinction and twinning patterns. Sample from the Joel prospect. Crossed polarizers. Scale is $1 \mathrm{~mm}$ long.

within the $T_{1}$ sites. Further ordering promotes the differentiation of the $\mathrm{T}_{1}$ sites into $\mathrm{T}_{1} \mathrm{O}$ and $\mathrm{T}_{1} \mathrm{~m}$, with the $\mathrm{Al}$ atoms in this case migrating preferentially to $\mathrm{T}_{1} \mathrm{O}$, and the structure becoming triclinic. Maximum ordering is attained when $\mathrm{Al}$ is fully within $\mathrm{T}_{1} \mathrm{O}$, and the other $\mathrm{T}$ sites containing only $\mathrm{Si}$ atoms, as for maximum microcline.

The average $\mathrm{Al}$ occupancies $(\mathrm{t}, \mathrm{o}, \mathrm{t}, \mathrm{m})$ of the $\mathrm{T}_{1} \mathrm{O}$ and $\mathrm{T}, \mathrm{m}$ sites are thus a good measure of the ordering state of a potassium feldspar structure. These parameters were computed for the Tapajós adularia samples on the basis of a triclinic unit cell refined dimensions, using both the $\mathrm{b}-\mathrm{c}$ and $\mathrm{y}^{*}-\alpha^{*}$ plots and the equations derived by Kroll and Ribbe (1983). The results are presented in table 2 and figure 5.
In all the three adularia samples $\mathrm{Al}$ atoms are highly ordered into the $\mathrm{T}_{1} \mathrm{O}$ sites. Sample Ad-1 from the Davi area (Table 2), with the most homogeneous triclinic diffraction pattern, has $t_{1} \mathrm{O}$ very close to the maximum value permitted which is 1 . Samples Ad-2 and Ad-3 from Joel present values of 0.94 and 0.96 , respectively. These numbers are somewhat lower than those of Ad-1, but even so within the range of highly ordered structures.

Samples Ad-2 and Ad-3 plot both near the maximum microcline corner (MM) of the b-c quadrilateral, respectively in and outside de limiting line (Fig. 5). The Davi sample Ad-1, on the other hand, is somewhat atypical for an Or-rich feldspar as there is a large departure 
Table $l$ - Representative microprobe analyses of adularia from the Tapajós region. Ad-1 = red adularia samples from Davi; Ad2 - pink adulana samples from Joel; Ad-3 = salmon pink adulana samples from Joel.

\begin{tabular}{|c|c|c|c|c|c|c|c|}
\hline \multicolumn{8}{|c|}{ Oxide content (wL \%) } \\
\hline Sample & $\mathrm{Ad}-1.1$ & Ad-1.2 & Ad-1.3 & Ad-2.1 & Ad-2.2 & Ad-3.1 & Ad-3.2 \\
\hline $\mathrm{SiO}_{2}$ & 65.05 & 65.07 & 65.19 & 64.73 & 64.85 & 64.70 & 65.14 \\
\hline $\mathrm{Al}_{2} \mathrm{O}_{3}$ & 18.04 & 18.26 & 18.30 & 18.26 & 18.20 & 18.25 & 18.29 \\
\hline $\mathrm{Fe}_{2} \mathrm{O}_{3}$ & 0.14 & 0.35 & 0.33 & nd & 0.02 & nd & nd \\
\hline $\begin{array}{l}\mathrm{CaO} \\
\mathrm{SrO}\end{array}$ & & nd & nd & nd & nd & nd & \\
\hline $\begin{array}{l}\text { Sro } \\
\mathrm{BaO}\end{array}$ & $\begin{array}{l}\text { nd } \\
0.45\end{array}$ & $\begin{array}{l}\text { nd } \\
0.37\end{array}$ & $\begin{array}{l}0.03 \\
0.31\end{array}$ & $\begin{array}{l}\text { nd } \\
0.41\end{array}$ & $\begin{array}{l}\text { nd } \\
0.18\end{array}$ & $\begin{array}{l}\text { nd } \\
0.40\end{array}$ & $\begin{array}{l}\text { nd } \\
0.16\end{array}$ \\
\hline $\mathrm{Na}_{2} \mathrm{O}$ & 0.24 & 0.12 & 0.09 & 0.75 & 0.52 & 0.52 & 0.39 \\
\hline $\mathrm{K}_{2} \mathrm{O}$ & 16.43 & 16.54 & 16.56 & 15.80 & 15.69 & 15.90 & 16.09 \\
\hline $\mathrm{Cs}_{2} \mathrm{O}$ & nd & 0.04 & nd & nd & nd & nd & \\
\hline Total & 100.35 & 100.75 & 100.82 & 99.95 & 99.46 & 99.78 & 100.07 \\
\hline \multicolumn{8}{|c|}{ Number of cations on the basis of 8 Oxigens } \\
\hline$\overline{\mathrm{Si}}$ & 3.01 & 3.00 & 3.00 & 3.00 & 3.01 & 3.00 & 3.01 \\
\hline Al & 0.98 & 0.99 & 0.99 & 1.00 & 0.99 & 1.00 & 0.99 \\
\hline $\mathrm{Fe}^{3+}$ & - & 0.01 & 0.01 & - & - & - & - \\
\hline$\Sigma \mathbf{r}$ & 3.99 & 4.00 & 4.00 & 4.00 & 4.00 & 4.00 & 4.00 \\
\hline $\mathrm{Ca}$ & - & - & - & - & - & - & - \\
\hline $\mathbf{S r}$ & - & - & - & - & - & - & - \\
\hline $\mathbf{B a}$ & 0.01 & 0.01 & 0.01 & 0.01 & - & 0.01 & - \\
\hline $\mathrm{Na}$ & 0.02 & 0.01 & 0.01 & 0.07 & 0.05 & 0.05 & 0.03 \\
\hline $\mathbf{K}$ & 0.97 & 0.97 & 0.97 & 0.93 & 0.94 & 0.94 & 0.96 \\
\hline Cs & - & - & - & - & - & - & - \\
\hline$\Sigma \mathbf{M}$ & 1.00 & 0.99 & 0.99 & 1.01 & 0.99 & 1.00 & 0.99 \\
\hline \multicolumn{8}{|c|}{ Molar proportions of feldspar end members } \\
\hline Or & 98 & 99 & 99 & 93 & 95 & 95 & 97 \\
\hline$A b$ & 2 & 1 & 1 & 7 & 5 & 5 & 3 \\
\hline $\mathrm{An}$ & & & & & & & \\
\hline
\end{tabular}

towards more Ab-rich compositions in that diagram. This can result from both chemical and strain effects.

The diffractometric and chemical data herein presented do no support a significant $\mathrm{Na}^{+}$content in sample Ad-1. Besides $\mathrm{Na}+$ substituting for $\mathrm{K}^{+}$within the alkali-feldspar series, $\mathrm{B}^{3+}$ substituting for $\mathrm{Al}^{3+}$ into tetrahedral sites is the only known element that could result in such a departure, as experimentally demonstrated for high sanidine (see Smith 1974a and references therein), but again there is not a major evidence for that. Microprobe results show very stoichiometric atomic proportions as stated in the previous section. Only one analytical point (sample Ad-1.1, Table 1) depicts a significant but very low Al deficiency, which should be attributed to analytical deviations rather than to a significant $\mathrm{B}^{3+}$ content.

Disregarding compositional effects, the observed deviations should be related to some sort of contrasting strain state. The possible effects of strain on the feldspar lattice of the Tapajós samples can be analyzed by computing the "Strain Index" (SI, \%) defined by Kroll and Ribbe (1987) on the basis of the a, b and c cell dimensions. Unstrained alkali-feldspars have SI close to 0, while strained Or-rich feldspars have $\mathrm{SI}>0$ and strained Ab-rich ones have $\mathrm{SI}<0$. Despite being very rich in the Or end member, the relatively Na-richer samples from the Joel prospect have a low SI value of about -3 (sample Ad-2) and a high value of about -7 percent (sample Ad-3), the latter plotting outside the b-c quadrilateral limits (Fig. 5). The Davi sample (Ad-1) shows a contrasting positive but low SI value of about +3 percent. Most of the strain evaluation methods like the one applied here have inherent limitations as extensively discussed by Kroll and Ribbe (1987) and Blasi and Blasi (1994). Despite this, it is suggested that contrasting strain should be the major factor on the observed lattice parameter deviations. It should be also added that wether such a difference could explain or not the large deviation of the Davi sample is a theme beyond the scope of the present study.

The data above indicative of a near maximum microcline structural state for the adularia of the two Tapajós prospects differ from data obtained in the majority of the studies carried out to date (e.g. Gubser and Laves 1967. Czerný and Chapman 1984). These studies show that most examined adularia have disordered monoclinic or low- to moderately-ordered triclinic structures. Data for selected samples from some well-known hydrothermal vein deposits examined by Czerny and Chapman (1986) and Dong and Morrison (1995) are also plotted in figure 5 for comparison. They indicate clearly that adularia spans a wide range of structural states covering from disordered to maximum ordered end-members. Strongly ordered triclinic varieties as in the case of Tapajós are relatively rare but have been found in quartz veins from the tungsten deposit of Xihuashan, China, and in amygdules in basalts form the locality of Kearsarge in the Michigan Copper District, USA.

FLUID INCLUSION DATA Fluid inclusions were analized in order to determine temperatures and composition of fluids as well as

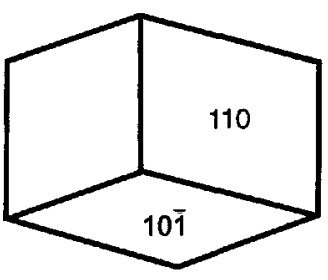

FELSÖBANYA

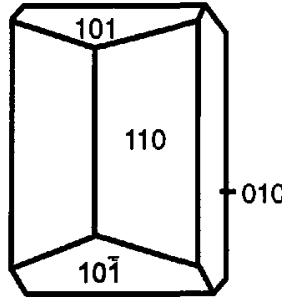

ZILLERTAL
Figure 3 - The "Felsöbanya " and "Zillertal" types of crystal morphology characteristic ofadularia (extracted from Smith 1974b).

to estimate the depth-pressure range for the growth of the adularia veins. All measurements were obtained from quartz crystals adjacent to adularia.

The least deformed quartz crystals were selected among samples available from the Davi workings. Although the crystals always exhibit a small degree of deformation, some contain inclusions of appropriate size ( 5 to $25 \mu \mathrm{m}$ ) to the experiments that can be recognized as primary and pseudosecondary, following criteria of Roedder (1984). They are two-phase (water-vapour), mostly liquid-rich inclusions that occur in clusters and along planes of healed microfractures. Some vapour-rich inclusions were also found coexisting with liquid-rich inclusions in one of the clusters. According to Bodnar et al. (1985), this feature may indicate entrapment from boiling fluids.

Liquid-rich inclusions from the Davi prospect homogenized over the range of $240^{\circ}$ to $320^{\circ} \mathrm{C}$ (Fig. 6a). The vapour-rich inclusions decrepitated on heating. Secondary inclusions were not analyzed due to their extremely small size. During freezing experiments, neither melting of solid $\mathrm{CO}_{2}$ nor nucleation of $\mathrm{CO}_{2}$ clathrates were observed. Freezing point depression measurements indicated the presence of dilute fluids with very low salinity, ranging from 0.35 to $5.71 \mathrm{wt} \%$ $\mathrm{NaCl}$ eq., and averaging 1.15 wt. \% $\mathrm{NaCl}$ eq.(Fig. 6b).

From the Joel area, perfectly idiomorphic and undeformed quartz crystals occurring along with adularia in cavities were selected. These crystals display two-phase (water-vapour), liquid-rich inclusions up to 10-15 urn in size. Most of them are primary, growth-zone inclusions that showed homogenization temperatures of $220^{\circ}$ to $340^{\circ} \mathrm{C}$ (Fig. 6a). $\mathrm{CO}_{2}$ was also not detected in the trapped fluids. The majority of the salinity values were found to be lower than at Davi, varying from 0.18 to 1.40 wt. $\% \mathrm{NaCl}$ eq. with an average of $0.43 \mathrm{wt} \% \mathrm{NaCl}$ eq. Some salinity results obtained from pseudosecondary inclusions were higher, attaining 9 - 11 wt. \% $\mathrm{NaCl}$ eq. (Fig. 6b).

As mentioned, vapour-rich inclusions found associated with liquidrich inclusions in one of the Davi samples are suggestive of boiling. However, it is not a widespread characteristic and cannot be considered as a definitive proof of boiling. Taking into account that the occurrence of adularia as an open space filling is admitted as a mineralogical indicator of boiling (Browne 1978, Henley 1985), the homogenization temperatures indicated above can be considered identical to the trapping temperatures and do not require pressure correction. Consequently, the hydrostatic pressure and the related depth of deposition can be estimated directly from the diagram for boiling solutions containing water and 0 to 5 wt. $\% \mathrm{NaCl}$ of Haas (1971). Taking the temperature bracket of $230^{\circ}$ to $330^{\circ} \mathrm{C}$, an interval of 30 to 120 bars for the hydrostatic pressure is obtained. This is consistent with a depth of 400 to $1,500 \mathrm{~m}$ for the formation of the adularia veins of the Davi and Joel prospects. However, it should be noted that the presence of small amounts of dissolved $\mathrm{CO}_{2}$ in the fluid, not usually detected by normal microthermometric studies (Bodnar et al. 1985), may affect these values, by lowering salinity and also increasing the depth-pressure estimates presented above.

COMMENTS ON THE ORIGIN OF ADULARIA Perfectly rhombic sections are identified in adularia of the Davi prospect, and feldspars with the crystal habit known as Felsobanya are observed in cavities of samples from the Joel area (Figs. 2C and 2D). These are morphological features that Czerný and Chapman (1986) consider typical of monoclinic adularia. Internal optical features in crystals such as variable or sector extinction patterns would also be indicative of crystallization in a disordered state, according to Akizuki and Sunagawa (1978). 

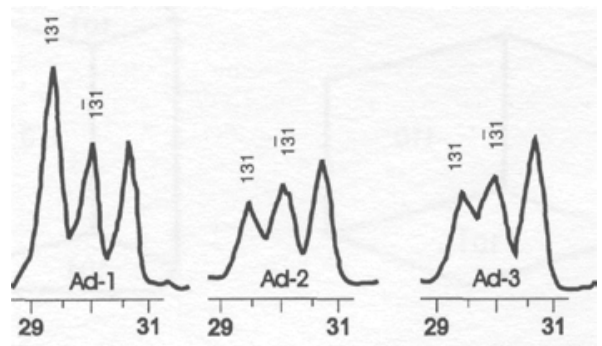

$2 \theta$

Table 2 - Unit-cell lattice parameters, regression errors andAl occupancies (tjo) within $\mathrm{TjO}$ sites of adularia from the Tapajós region Samples Ad-1, -2, -3 as in figure 4. Al occupancies computed from equations of Kroll and Ribbe (1983).

\begin{tabular}{|l|l|l|l|l|l|l|l|}
\hline Sample & $\begin{array}{l}\text { a } \\
(\AA)\end{array}$ & $\begin{array}{l}\text { b } \\
(\AA)\end{array}$ & $\begin{array}{l}\text { c } \\
(\AA)\end{array}$ & $\begin{array}{l}\alpha \\
(\mathrm{deg})\end{array}$ & $\begin{array}{l}\beta \\
(\mathrm{deg})\end{array}$ & $\begin{array}{l}\gamma \\
(\mathrm{deg})\end{array}$ & $\mathrm{t}_{\mathrm{i}} \mathrm{O}$ \\
\hline Ad-1 & $8.590(4)$ & $12.948(5)$ & $7.216(2)$ & $90.61(2)$ & $115.96(3)$ & $87.87(3)$ & 0.99 \\
Ad-2 & $8.599(3)$ & $12.964(4)$ & $7.221(3)$ & $90.60(2)$ & $115.93(2)$ & $87.91(4)$ & 0.94 \\
Ad-3 & $8.594(3)$ & $12.968(4)$ & $7.223(2)$ & $90.58(3)$ & $115.95(3)$ & $87.83(4)$ & 0.96 \\
\hline
\end{tabular}

Figure 4 - X-ray partial diffraction pattern showing the $131+1 \overline{3} 1$ peak configurations of representative samples of adularia from the Tapajós region. Ad-1 = red adularia from the Davi prospect, Ad-2 = pink sample from Joel, Ad-3 = salmon pink adularia from Joel.

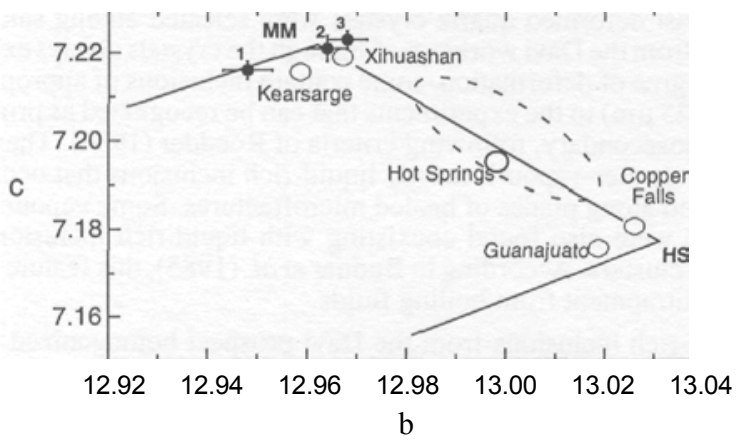

Figure 5 - Plot of b versus c lattice parameters for the topologically triclinic K-feldspar region: maximum microcline (MM) and highsanidine (HS) end members are from Kroll and Ribbe (1983). Representative samples Ad-1, -2 and -3 as in Figure 4 plotted as filled circles with bars for regression errors. Empty circles are for adularia from some well known hydrothermal vein deposits studied by Czerný and Chapman (1986). Dotted area encompasses data for a large number of adularia samples from Queensland, Australia, examined by Dong and Morrison (1995).

However, the diffractometric data demonstrate that the adularia specimens here investigated are structurally ordered, displaying unit cell dimensions similar to those of maximum microcline. This is interpreted (e.g. Gubser and Laves 1967) as a result of metastable crystallization of a disordered, monoclinic feldspar followed by a process of ordering controlled mainly by the thermal regime after crystallization. The alternative hypothesis of the direct crystallization of adularia as a triclinic phase is unsustainable in view of the evidence of preservation of morphological monoclinic features in the feldspars of Tapajós.

A high rate of nucleation and crystal growth under low temperatures is the most accepted explanation for the generation of a metastable feldspar, according to Laves (1952) and Dong and Morrison (1995). This could be achieved by means of a sudden decompression of fluids, triggered perhaps by tectonic activity or hydraulic fracturing with formation of breccias, fractures and cavities in rocks. Decompression in hydrothermal systems is usually accompanied by boiling, and this mechanism is frequently referred to as one of the most important and efficient processes in the deposition not only of adularia and other gangue minerals but of the ore as well (Henley 1985).

Adiabatic boiling induces fast cooling of the fluid due to vapour escape from the fluid. The chemical changes the fluid undergoes include a raise in $\mathrm{pH}$ caused by the partitioning of volatiles preferentially into the steam phase and an increase in concentration of nonvolatile constituents that remain in the liquid phase as a result of the separation of steam (Fournier 1985). These factors promote supersaturation, which results in the sudden precipitation of silica, sulfides and precious metals, along with metastable potassium-rich feldspar, preferentially in fractures and as filling material between breccia fragments.

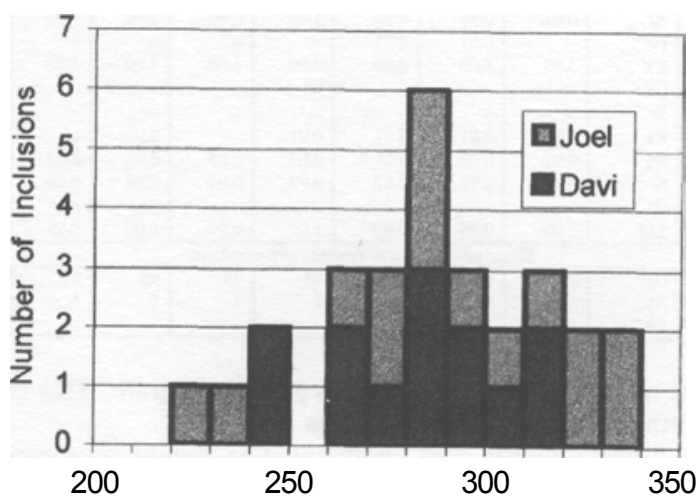

Temperature of Homogenization $\left({ }^{\circ} \mathrm{C}\right)$

B

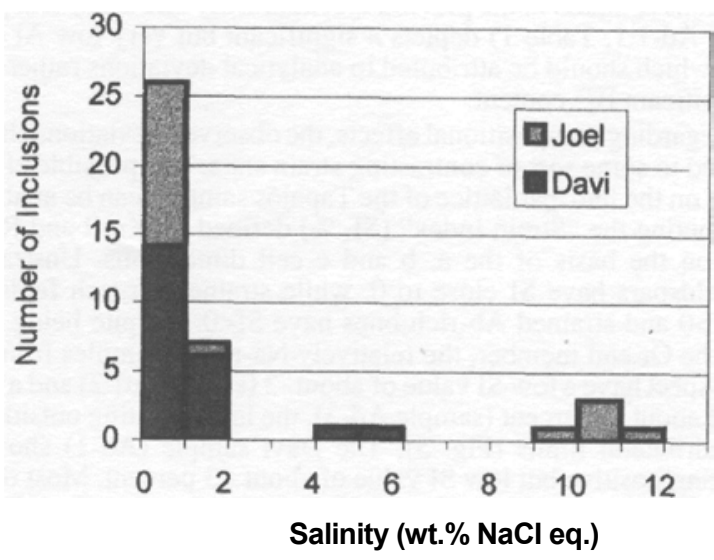

Figure 6 - (A) Temperature of homogenization and (B) salinity data for fluid inclusions in quartz adjacent to adularia from the Davi and Joel prospects.

The advanced degree of ordering attained by the adularia of the Tapajós region after crystallization probably bears some relation with an extensive action of late fluids. This is supported by studies of Czerný and Chapman (1986) at various hydrothermal settings, which indicate that the most ordered varieties of adularia are invariably altered and substituted by secondary minerals. The action of late fluids on feldspars of the occurrences of the Tapajós region is unequivocal and particularly intense in the case of the Davi prospect. It may be verified through the substitution of feldspar by chlorite, calcite, epidote, prehnite and ferruginous-clayey material.

IMPLICATIONS FOR GOLD METALLOGENY IN THE TAPAJÓS PROVINCE Primary gold of the Tapajós Province occurs generally in quartz veins, although disseminations and stockworks have also been reported (Faraco et al. 1996). Wallrocks are mainly gneisses and Lower Proterozoic granites but gold showings hosted by 
Middle Proterozoic volcanic rocks and associated granites are also quite widespread. An epithermal / epizonal model (Martini and Dreher 1996a, b) with deposits genetically related to the younger granites has been suggested for the bulk of the mineralization (Robert 1996). The model would apply to typical volcanic-hosted epithermal veins as well as to veins occurring in the older granites and gneisses, already raised to epizonal conditions by the time of gold mineralization. It would also include possible porphyry-type occurrences located inside the gold-related intrusions (Coutinho et al. 1997). Mesothermal veins associated with ductile deformation have been considered uncommon in the Tapajós region (Robert 1996, Santos 1996, 1997). Gold occurrences in quartz veins hosted by mafic rocks such as those of the Davi and Joel prospects have generally been compared with mesothermal veins (Bastos Leal and Tassinari 1994, Coutinho 1996). Santos et al. (1997), in turn, using a $\mathrm{Pb} / \mathrm{Pb}$ age of $1.83 \mathrm{Ga}$ obtained from sulfides, relate the mineralization at Davi to the regional heating associated with the Middle Proterozoic magmatism.

The presence of adularia in gold occurrences of the Tapajós region, previously suggested in a report on the Davi prospect (Martini and Dreher 1996a) and confirmed in the present work, represents an important contribution towards a more precise definition of the typology of gold deposits of this mineral province. In fact, adularia constitutes a critical and characteristic mineral of veins of the so-called adularia-sericite epithermal category of Heald et al. (1987), also referred to as low sulfidation type deposits by Sillitoe (1993). In the alternative acid-sulfate, or high sulfidation group of epithermal deposits adularia is always absent.

In adularia-sericite gold deposits, adularia occurs typically in veinlets and cavities associated with the mineralized quartz veins, a characteristic identified in the Davi and Joel prospects. Other minerals present such as sphalerite, galena, calcite, epidote, chlorite, prehnite, albite and fluorite are also more frequently found in adularia-sericite than in acid-sulfate deposits. At Joel, the wallrock alteration is in accordance with the pattern indicated by Heald et al. (1987), showing a zone of intense sericitization adjacent to the veins, which grades outwards to a propyllitic zone. The Davi prospect exhibits a more complex picture, involving albitized portions and calcite plus prehnite veinlet zones near the vein, which nevertheless is also represented in epithermal deposits of the adularia-sericite type (Siems 1991).

Other aspects formerly mentioned in this text reinforce the characterization of the epithermal nature of the two gold occurrences under scope. These aspects include the shallow emplacement of the veins, as indicated by the open-space filling textures of the quartz-adularia veins; the non-metamorphic nature of the vein wallrocks; and the evidence of brittle deformation as expressed by friction striae and strong fracturing and brecciation exhibited by wallrocks and or mineralized veins.

Fluid inclusions data, although restricted to inclusions in quartz adjacent to adularia, show that the trapped fluids are either $\mathrm{CO}_{2}$-free or possibly contain only small amounts of $\mathrm{CO}_{2}$. This is in agreement with the characteristics of fluid inclusions from epithermal environ- ments (Bodnar et al. 1985). The salinity values were found to be low in general, averaging $1.15 \mathrm{wt} \% \mathrm{NaCl}$ eq. for Davi and 0.43 wt. \% $\mathrm{NaCl}$ eq. for Joel, with exceptional values of up to 9-11 \% NaCl. These numbers are within the range of 0 to $13 \mathrm{wt} . \% \mathrm{NaCl}$ eq. of composition of epithermal adularia-sericite deposits (Heald et al. 1987).

Important reviews on epithermal deposits (Heald et al. 1987, Sillitoe 1989, 1993, White and Hedenquist 1990, 1995) demonstrate that mineral deposition in these systems occurred mostly between $100^{\circ}$ and $320^{\circ} \mathrm{C}$. Investigation of active geothermal fields, considered as present-day analogous to ancient epithermal systems, indicates that alteration minerals such as adularia are formed up to least $350^{\circ} \mathrm{C}$ (Henley and Ellis 1983, Henley 1991). Thus, homogenization data of $220^{\circ}$ to $340^{\circ} \mathrm{C}$ obtained in the present study belong to the upper range of temperatures found in epithermal deposits. This may indicate that adularia and associated mineralization at Davi and Joel correspond to deep epithermal occurrences, i.e., both prospects probably represent exposures of rocks found in deeper and higher temperature portions of the related hydrothermal systems. In favour of this possibility are the following points: a) the veins are hosted by subvolcanic instead of volcanic rocks where the classic epithermal deposits are commonly found; b) the veins contain crystalline quartz associated with adularia, and do not show the colloform or chalcedonic textures typical of shallower zones in epithermal deposits (Morrison et al. 1990); c) the paleodepths of up to $1.5 \mathrm{~km}$ estimated from fluid inclusion data indicate that the Davi and Joel gold-adularia occurrences represent relatively deep levels of epithermal hydrothermal activity, as depth limits of such systems are admittedly of the order of 1-2 km (Hedenquist and Lowenstern 1994).

Two other aspects are worth emphasizing with respect to the typology of the gold mineralization of Tapajós as characterized here. The first one is that the hosting epizonal setting is of Proterozoic age. This is quite unusual as epithermals are mostly found in Cenozoic environments, and reinforces the thesis that this kind of deposit may be present wherever conditions for their generation and preservation occurred in the geological record (e.g. Henley 1991). The second aspect refers to the importance of this type of mineralization for the mining industry, as epithermal deposits are considered highly favorable exploration targets due to their potential for generating bulk tonnage gold deposits.

Acknowledgements This paper is a contribution to the Tapajós Mineral Province Project of CPRM, Geological Survey of Brazil. CPRM provided the necessary support. Thanks are also due to R.P.Xavier, D.Silva and H.Kahn for providing fluid inclusion and X-ray facilities, to J.Negreiros, J.M.V.Coutinho and M.Silva for mineralogical support and assistance with photographic equipment, to F.Robert for his interest in this study and to M.Thompson for the revision of the English version. Comments and criticism of two anonymous reviewers greatly improved the final text. SRFV thanks FAPESP (Proc. 95/5729-9).

\section{References}

Akizuki, M. \& Sunagawa, I. 1978. Study of the sector structure in adularia by means of optical microscopy, infra-red absorption, and electron microscopy. Mineralogical Magazine, 48:453-462.

Bastin, G.F.; van Loo, F.J.J.; Heijligers, H.J.M. 1984. Evaluation and use of gaussian ( $\Phi(\mathrm{pz})$ curves in quantitative electron probe microanalysis: a new optimization. X-ray Spectrometry, 13:91-97.

Bastos Leal, L.R. \& Tassinari, C.C.G. 1994. Características das mineralizações auríferas filoneanas dos garimpos do Creporizinho e Creporizão, Província Aurífera do Tapajós, PA. In: SBG, Congresso Brasileiro de Geologia, 38, Camboriú. Anais, Tapajós, PA.

Blasi, A. \& Blasi, C.P. 1994. Aspects of alkali-feldspar characterization: prospects and relevance problems outstanding. In: I. Parsons (ed.) Feldspars and their reactions. NATO ASI Series C. vol. 421, p. 51-102.

Bodnar, R.J.; Reynolds, T.J.; Kuehn, C.A. 1985. Fluid-inclusion systematics in epithermal systems. In: B.R. Berger \& P.M. Bethke (eds.) Geology and geochemistry of epithermal systems. Society of Economic Geologists, p. 73-97. (Reviews in Economic Geology 2).

Bodnar, R.J. 1993. Revised equation and table for determining freezing point depression of FhO-NaCl solutions. Geochimica et Cosmochimica Acta, 57:683-684.

Borg, I.Y. \& Smith, O.K. 1969. Calculated X-ray powder patterns for silicate minerals. Geological Society of America Memoir, 122, $896 \mathrm{p}$.

Browne, P.R.L. 1978. Hydrothermal alteration in active geothermal fields. Annual Review of Earth and Planetary Sciences, 6:229-250.

Burnham, C.W. 1962. Lattice constant refinement. Carnegie Institute of Washington Yearbook, $6 l: 132-135$.
Coutinho, M.G.N. 1996. Áreas Garimpo Batalha e Garimpo Davi. Série Estudos de Prospectos 2A/96. CPRM, Projeto Província Mineral do Tapajós, Relatório Interno, $22 \mathrm{p}$

Coutinho, M.G.N.; Liverton, T.; Souza, E.C. 1997. Granitic magmatism and related gold mineralization in the Tapajós Mineral Province, Amazonian area, Brazil. In: CBPM-SGM / Salvador, 2nd. International Symposium on Granites and Associated Mineralization, Extended Abstracts and Program, 46-47.

Czerný, P. \& Chapman, R. 1984. Paragenesis, chemistry and structural state of adularia from granitic pegmatites. Bulletin Minéralogique, 107:369-384.

Czerný, P. \& Chapman, R. 1986. Adularia from hydrothermal vein deposits: extremes in structural state. Canadian Mineralogist, 24:717-728.

Deer, W.A.; Howie, R.A.; Zussman, M.A. 1971. Rock-forming minerals. 4. Framework silicates. London, Longman, $435 \mathrm{p}$

Dong, G. \& Morrison, G.W. 1995. Adularia in epithermal veins, Queensland: morphology, structural state and origin. Mineralium Deposita, 30:11-19.

Faraco, M.T.L.; Carvalho, J.M.A.; Klein, E.L. 1996. Carta metalogenética da Província Aurífera do Tapajós. Escala 1:500.000. Nota explicativa. CPRM-Superintendência Regional de Belém, 13p.

Fournier, R.O. 1985. The behavior of silica in hydrothermal solutions. In: B.R. Berger, \& P.M. Bethke (eds.) Geology and geochemistry of epithermal systems. Society of Economic Geologists, p. 45-62. (Reviews in Economic Geology 2).

Goldsmith, J.R. \& Laves, F. 1954. The microcline-sanidine stability relations. Geochimica et Cosmochimica Acta, 5:1-19.

Gubser, R. \& Laves, F. 1967. On X-ray properties of "adularia", (K,Na) $\mathrm{AlSi}_{3} \mathrm{O}_{8}$. Schweizerische Mineralogische und Petrographische Mitteilungen, 47:177-188.

Haas, J.L. 1971 The effect of salinity on the maximum thermal gradient of a hydrothermal system at hydrostatic pressure. Economic Geology, 66:940-946. 
Heald, P.; Fotey, N.K.; Hayba, D.O. 1987. Comparative anatomy of volcanic-hosted epithermal deposits: acid sulphate and adularia-sericite types. Economic Geology, $82 \cdot 1-26$

Hedenquist, J.W. \& Lowenstern, J.B. 1994. The rote of magmas in the formation of hydrothermal ore deposits. Nature 370:519-527.

Henley, R.W. 1985. The geothermal framework of epithermal deposits. In: B.R. Berger \& P.M. Bethke (eds.) Geology and geecftemisiry of epithermal systems. Society of Economic Geologists, p. 1-24. (Rèvie ${ }^{\mathrm{t}}$ in Economic Geology 2).

Henley, R.W. 1991. Epithermal gold deposits in volcanic terranes. In: R.P. Foster (ed.) Gold Exploration and Metallogeny, London, Blackie, p. 133-164.

Henley, R.W. \& Ellis, AJ. 1983, Geothermal systems ancient and modern: a geochemical review, Earth Scijnce Reviews, 19:1-50.

Kroll, H. \& Ribbe, P.H. 1983. Lattice parameters, composition and Al, Si order in alkali feldspars. In: P.H. Ribbe (ed.) Feldspar Mineralogy. 2nd edition. Blacksburg, Virginia. Mineralogical Society of America, p. 57-99. (Reviews in Mineralogy 2).

Kroll, H. \& Ribbe, P.H. 1987. Determining (Al, Si) distribution and strain in alkali feldspar using lattice parameters and diffraction-peak positions. A review. American Mineralogist, 72: 491-506.

Laves, F. 1952. Phase relations of the alkali felspars. Journal of Geology, 60:436.

Martini, S.L. \& Dreher, A.M. 1996a. Visita aos garimpes Batalha e do Davi: dados geológicos e petrográficos. CPRM, Projeto Província Mineral do Tapajós, Relatório Interno, $4 \mathrm{p}$.

Martini, S.L. \& Dreher, A.M, 1996b, Visite aos garimpos N. S. da Conceição, Bom Jesus e Cuiú-Cuiú. CPRM, Projeto Província Mineral do Tapajós, Relatório Interno, 7p.

Morrison, G.; Dong, G,; Jaireth, S. 1990. Textural zoning in epithermal quartz veins. Townsville, Australia, Klondike Exploration Services, 19p.

Robert, F. 19\%. Tapajós Gold Project, Para State, Brazil. Canada-Brazil Cooperation for Sustainable Development in the Minerals Sector. Geological Survey of Canada, Mission Report. 35p.

Roedder, E. 1984. Fluid Inclusions. In: P.H. Ribbe (ed.) Reviews in Mineralogy, 12, 2nd edition, Blacksburg, Virginia, Mineralogical Society of America. $646 \mathrm{p}$.

Santos, J.O.S. \& Loguercio, S.O.C. 1984. A parte meridional do Cráton Amazônico (Escudo Brasil-Central) e as bacias do Alto Tapajós e Parecis-Alto Xingu. In: C Schobbenhaus; D.A. Campos; G.R. Derze; H.E. Asmus (eds.) Geologia do Brasil, Brasília, DNPM/DGM, p. 93-127.
Santos, J.O.S.; Hartmann, L.A.; Gaudette, H.E., 1997. Reconnaissance U/Pb in zircon, $\mathrm{Pb} / \mathrm{Pb}$ in sulfides and review of $\mathrm{Rb} / \mathrm{Sr}$ geochronology in the Tapajós Gold Province, Pará/Amazonas States, Brazil. In: CPGeo-IGUSP / Campos do Jordão, South-American Symposium on Isotope Geology, Extended Abstracts, 280-282.

Santos, R.A.I 996. Contribuição à análise estrutural de jazimentos auríferos do Rio Tapajós, SW do Pará: Garimpos Chico Torres, São José, Mamoal e Jutaí. CPRM, Projeto Província Mineral do Tapajós, Relatório Interno, 1Op.

Santos, R.A. 1997. Contribuição à análise estrutural de jazimentos auríferos do Rio Tapajós, SW do Pará e SE do Amazonas: Garimpos Abacaxis, Espírito Santo, Bom Jesus, Goiano, Fazenda Pison, Ouromil, Santa Isabel, Majestade e Carneirinho. CPRM, Projeto Província Mineral do Tapajós, Relatório Interno, $11 \mathrm{p}$

Schobbenhaus, C.; Campos, D.A.; Derze, G.R.; Asmus, H.E. 1984. Mapa Geológico do Brasil e da área oceânica adjacente incluindo depósitos minerais. Escala 1:2.500.000. Brasília, DNPM/DGM.

Siems, P.L. 1991. Hydrothermal alteration for mineral exploration workshop. Lecture Manual. University of Idaho, $582 \mathrm{p}$.

Sillitoe, R.H. 1989. Gold deposits in Western Pacific island arcs: the magmatic connection. Economic Geology Monograph 6, p. 274-291.

Sillitoe, R.H. 1993. Epithermal models: Genetic types, geometrical controls and shallow features. In: R. V. Kirkham, W.D. Sinclair, R.I. Thorpe and J.M. Duke (eds.)Mineral Deposit Modeling. Geological Association of Canada Special Paper 40, p. 403-417.

Smith, J.V. 1974a. Feldspar Minerals. I. Crystal structure and physical properties. New York, Springer-Verlag, $1627 \mathrm{p}$

Smith, J.V. 1974b. Feldspar Minerals. II. Chemical and textural properties. New York, Springer-Verlag, $2690 \mathrm{p}$.

White, N.C. \& Hedenquist, J.W. 1990. Epithermal environments and styles of mineralization: variations and their causes, and guidelines for exploration. Journal of Geochemical Exploration, 36:445-474.

White, N.C. \& Hedenquist, J.W. 1995. Epithermal gold deposits: styles, characteristics and exploration. Society of Economic Geologists Newsletter 13, p. 1,9-13.

Manuscrito A-995 Recebido em 17 de junho de 1998 Revisão dos autores em 15 de setembro de 1998 Revisão aceita em 01 de outubro de 1998 